\title{
Fire impacts tropical communities of soil fungi through changes to plant community composition, litter and soil chemistry
}

1 Jed Calvert ${ }^{1,2}$, Alistair McTaggart ${ }^{1}$, Lília C. Carvalhais ${ }^{1}$, André Drenth $^{1}$, Roger Shivas ${ }^{1}$

$2 \quad{ }^{1}$ Centre for Horticultural Science, Queensland Alliance for Agriculture and Food Innovation, The University of

3 Queensland, Ecosciences Precinct, 41 Boggo Rd Dutton Park, Queensland 4102, Australia

$4{ }^{2}$ Corresponding author at: Centre for Horticultural Science, Queensland Alliance for Agriculture and Food

5 Innovation, The University of Queensland, Ecosciences Precinct, 41 Boggo Rd Dutton Park, Queensland 4102,

$6 \quad$ Australia.E-mail address: j.calvert@uq.net.au (J.Calvert).

\section{Abstract}

8 Fire has been predicted to be more severe and frequent in forests of the Australian Monsoon

9 Tropics over the coming decades. The way in which groups of ecologically important soil fungi

10 respond to disturbance caused by fire has not been studied in tropical forest ecosystems.

11 Ectomycorrhizal (EM) fungi are important tree symbionts and saprotrophic fungi drive soil

12 nutrient cycles. We analysed both publicly-available environmental DNA sequence data as well as

13 soil chemistry data to test a hypothesis that fire events $(1970-2017)$ in a contiguous tropical

14 forest have altered the composition and diversity of EM and saprotrophic soil fungi. We tested this

15 hypothesis by measuring community-level taxonomic composition, fungal diversity, species richness and evenness. We determined whether changes in fungal communities were associated with fire-altered soil chemical/physical properties, vegetation types, or the direct effect of fire. Soil fungi differed in abundance and community phylogenetic structure between forest sites that had experienced fire, and those sites dominated by unburned forest. Communities of EM fungi were structurally altered by fire at shallow soil horizons, as well as by vegetational changes between burned and unburned sites at deeper soil horizons. In contrast, fires influenced community composition of saprotrophic fungi by changing soil nutrient levels and altering litter composition. Pyrophilic, truffle-like EM fungi that rely on mycophagous mammals for dispersal 
26 levels and altering litter composition.

\section{Graphical abstract}

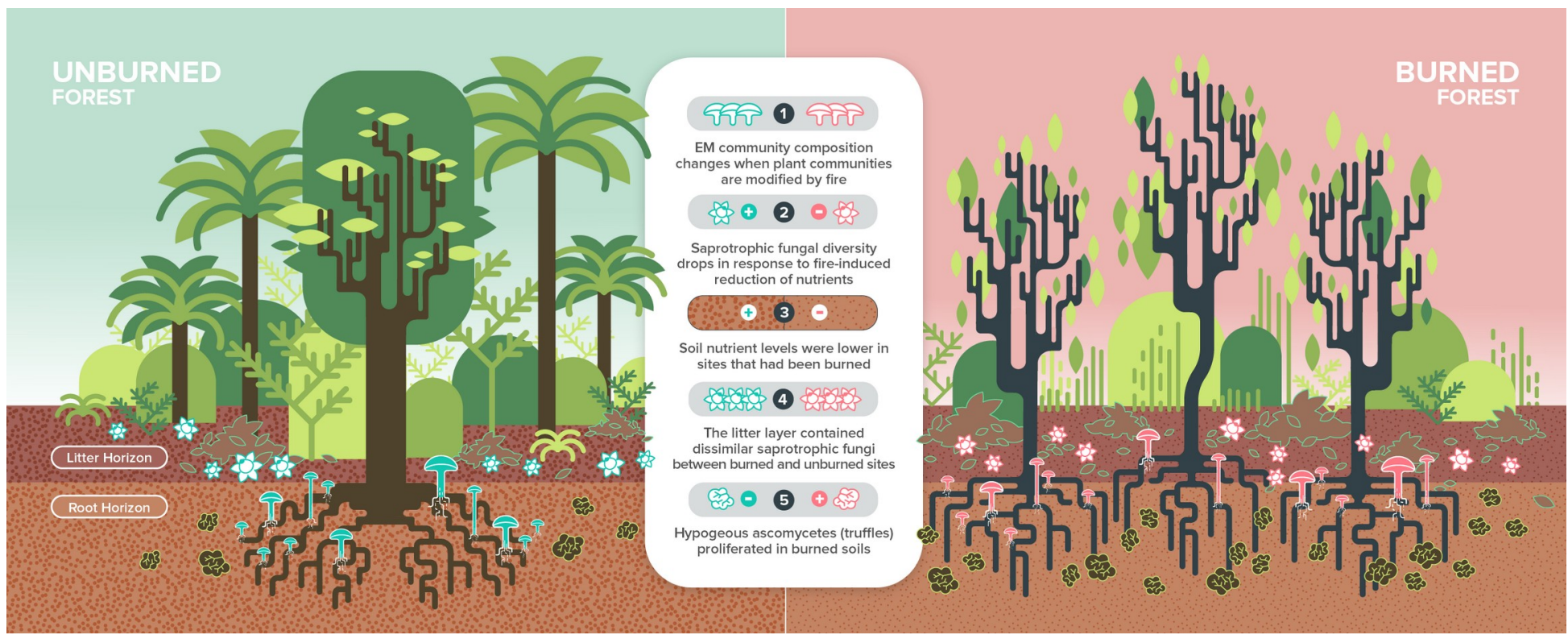

Credit: Sofia Houghton (2-column fitting image. Color to be used in print.)

Keywords

Soil, fungi, fire, ectomycorrhizal, saprotrophic, trophic, tropical, diversity, disturbance

\section{Introduction}

Soils contain some of the most complex and understudied ecosystems in terrestrial biomes, providing habitat for an estimated $25 \%$ of described species (Decaëns et al., 2010). Most of the terrestrial carbon on Earth is in soils (Crowther et al., 2016), and they have been designated a 'third biotic frontier' after deep-sea benthic regions and tropical rainforest canopies (Hågvar, 1998). Healthy soil ecosystems are undergirded by diverse communities of microorganisms dominated by fungi, bacteria, archaea and other eukaryotes, the taxonomy and function of which are largely unknown (Baldrian, 2019). Together, the microorganisms of this 'living terrestrial skin' drive global biogeochemical cycles and power terrestrial ecosystems (Tecon and Or, 2017). 
Fire is a major driver of disturbance in tropical forests (Silvério et al., 2019), including the

Australian Monsoon Tropics (AMT), which is the most fire-prone region in Australia (Bowman et

al., 2010). In the AMT, fire frequently intrudes from savanna into notophyll plant communities

and initiates a process of post-fire seral development (Bowman, 2009; Cole et al., 2014). In this

region, fire is a primary determinant of plant distribution, which in turn can influence the structure

of microbial communities (Ettema and Wardle, 2002; Ondei et al., 2016; Sarmiento et al., 2017).

An increase in fire frequency, severity and duration in the AMT is likely over the next decades due to anthropogenic climate change (Hubnerova et al., 2020). trophic modes. The resilience of tropical ectomycorrhizal (EM) fungi after fire has been attributed to their ability to draw nutrients from plants (Alem et al., 2020). Fires impact soil microorganisms through changes in soil $\mathrm{pH}$, water holding capacity, and availability of organic carbon, nitrogen and phosphorus (Pellegrini et al., 2019; Singh, 1994; Verma and Jayakumar, 2018). Soil enzyme activity, which reflects microbial metabolism in soil communities, also decreases immediately following fires, especially at shallow soil horizons (Certini et al., 2021). How different functional guilds of fungi respond to fire in a single tropical soil ecosystem has not been studied. down soil organic matter (SOM) (Fernandez and Kennedy, 2016). Gadgil and Gadgil $(1975,1971)$ proposed that competition and inhibition between saprotrophic and EM fungi suppress the decomposition of organic matter and increase the accumulation of organic carbon. Studies in northern-hemisphere coniferous ecosystems based solely on post-fire observations of macrofungal sporocarps are inconclusive, reporting lower EM diversity (Owen et al., 2019), higher saprotroph

61 diversity and proliferation of rare pyrophilous species (Salo et al., 2019). Similar studies on the

62 effect of fire on communities of saprotrophic and EM fungi in tropical forests have not been made. 

the Biomes of Australian Soil Environments soil microbial diversity database to test the hypothesis that fire events $(1970$ - 2017) in a contiguous tropical forest have altered the composition and diversity of EM and saprotrophic soil fungi. BASE maps Australia's soil microbial diversity using culture-independent high-throughput DNA sequencing (Bissett et al., 2016). We measured community-level taxonomic composition, diversity, species richness and evenness. We determined whether observed changes were associated with the burn status (burned/unburned) of a site, the recency of a fire, and whether these changes were a result of altered soil chemical/physical properties or vegetation type due to fire. Understanding the response of soil microbe communities to fire in the AMT may provide management options for the protection of ecosystems under a changing climate.

\section{Materials and methods}

\subsection{Study site}

The Iron Range on Cape York Peninsula, Far North Queensland, is a mountainous coastal region of the Australian Monsoon Tropics (AMT) dominated by tropical rainforest and notophyll vine forest (Neldner and Clarkson, 1995; Webb, 1959). Sample sites for this study were selected to represent a spectrum of seral stages, from unburned to recently burned (Table 1).

\subsection{Sampling BASE data}

We downloaded 42 fungal amplicon community profiles from unburned and burned sites from the Biomes of Australian Soil Environments microbial diversity database (BASE), which were sampled and sequenced according to Bissett et al. (2016). The BASE project took soil samples of $1 \mathrm{~kg}$ from the litter $(0-10 \mathrm{~cm})$ and mineral soil $(20-30)$ in February 2017. Soil chemical/physical properties including ammonium $\left(\mathrm{NH}_{4}\right)$, nitrate $\left(\mathrm{NO}_{3}\right)$, phosphorus $(\mathrm{P})$, 
88 from samples as per protocols of the Earth Microbiome Project

89 (http://www.earthmicrobiome.org/emp-standard-protocols/dna-extraction-protocol/). The ITS1

90 region of fungal ribosomal DNA was amplified with the primers ITS1F and ITS4 (Gardes and

91 Bruns, 1993; White et al., 1990) and sequenced with 300 bp paired-end chemistry on an Illumina

92 MiSeq.

93 Table 1 Study sites, fire history and floristic composition. (2-column fitting table.)

\begin{tabular}{|c|c|c|c|c|}
\hline Site & Fires ceased & Vegetation type & Dominant trees & Dominant grasses \\
\hline 1 & 2017 & Grassy woodland & $\begin{array}{l}\text { Corymbia intermedia, Lophostemon } \\
\text { suaveolens, Acacia flavescens }\end{array}$ & $\begin{array}{l}\text { Heteropogon contortus, } \\
\text { Imperata cylindrica }\end{array}$ \\
\hline 2 & 1995, one in 2014 & Shrubland & Dodonoea viscosa & None \\
\hline 3 & 1970, one in 2006 & Regenerating closed canopy forest & $\begin{array}{l}\text { Dillenia alata,Buchanania } \\
\text { arborescens, Guioa acutifolia } \\
\text { Blepharocarya involucrigera }\end{array}$ & $\begin{array}{l}\text { Crytococcum oxyphyllum, } \\
\text { Entolasia stricta }\end{array}$ \\
\hline 4 & 1970 & Regenerating closed canopy forest & $\begin{array}{l}\text { Atractocarpus sessilis, Buchanania } \\
\text { arborescens, Acacia midgleyi }\end{array}$ & None \\
\hline 5 & 1970 & Regenerating closed canopy forest & $\begin{array}{l}\text { Phyllanthus praelongipes, Mallotus } \\
\text { resinosus, Mallotus polyadenos, } \\
\text { Rinoria bangalensis }\end{array}$ & None \\
\hline 6 & Unburned & Regenerating closed canopy forest & $\begin{array}{l}\text { Nauclea orientalis, Bucanania } \\
\text { arborescens, Vitex heligiton }\end{array}$ & None \\
\hline 7 & Unburned & $\begin{array}{l}\text { Semi-deciduous mesophyll/notophyll } \\
\text { forest }\end{array}$ & $\begin{array}{l}\text { Tetrameles nudiflora, Cordia dichotima, } \\
\text { Canarium australianum, Lagerstroemia } \\
\text { archeriana, Vitex helogiton }\end{array}$ & None \\
\hline 8 & Unburned & $\begin{array}{l}\text { Semi-deciduous mesophyll/notophyll } \\
\text { forest }\end{array}$ & $\begin{array}{l}\text { Cordia dichotima, Tetrameles nudiflora, } \\
\text { Berrya javanica, Paraserianthes toona, } \\
\text { Mimusops elengi }\end{array}$ & None \\
\hline 9 & Unburned & $\begin{array}{l}\text { Semi-deciduous mesophyll/notophyll } \\
\text { forest }\end{array}$ & $\begin{array}{l}\text { Tetrameles nudiflora, Blepharocarya } \\
\text { involucrigera, Alstonia scholaris, } \\
\text { Aleurites moluccana }\end{array}$ & None \\
\hline 10 & Unburned & Wet rainforest & $\begin{array}{l}\text { Terminalia complanata, Palaquium } \\
\text { galactoxylom, Garcinia dulcis, } \\
\text { Syzygium pseudofastigiatum }\end{array}$ & None \\
\hline 11 & Unburned & Wet rainforest & $\begin{array}{l}\text { Aleurites moluccana, Neonauclea } \\
\text { glabra, Canarium australianum var. } \\
\text { australianum, Archidendron hirsutum }\end{array}$ & None \\
\hline
\end{tabular}

\section{2.3. Processing of sequence data}

ITS1 reads were identified and extracted with ITSx v1.1.3 (Bengtsson-Palme et al., 2013).

96 Quality filtering and construction of operational taxonomic unit (OTU) tables were performed in 
QIIME2 v2020.11 (Bolyen et al., 2018) with the dada2 denoise-single, phylogeny align-

to-tree-mafft-fasttree,

diversity

core-metrics-phylogenetic

and

feature-

classifier classify-sklearn functions. OTUs were generated from sequences with $97 \%$

similarity, and taxonomy was assigned using the UNITE v8.2 fungal database (Abarenkov et al.,

sequences per sample, based on rarefaction curves of Shannon's diversity index.

\subsection{Statistical analyses}

Soil chemistry data for each site were analysed to establish whether nutrient content was

correlated between samples exposed to fire at different time points and fungal community

Team, 2020) based on Bray-Curtis dissimilarities (Bray and Curtis, 1957) with the function vegdist in Vegan v2.5-6 (Oksanen et al., 2020) and visualized with non-metric multidimensional scaling (NMDS) (function metaMDS). Soil chemical/physical properties were analysed for $\mathrm{NH}_{4}$,

$110 \mathrm{NO}_{3}, \mathrm{P}, \mathrm{K}, \mathrm{C}, \mathrm{Ca}$ and $\mathrm{pH}$. To establish whether fire history and other factors structured soil fungal

111 communities, we constructed distance matrices from OTU tables based on unweighted UniFrac

112 (Lozupone and Knight, 2005), which measures OTUs in terms of their phylogenetic relatedness

113 and presence or absence between samples. We built PERMANOVA (adon is) forward models in R

114 to assess variance between categorical variables related to soil chemical/physical properties and

115 determine the significance and hierarchy of influence for sample depth, burn status

116 (burned/unburned), vegetation type (shrubland, grassy woodland, regenerated closed canopy

117 forest, semi-deciduous notophyll forest, wet rainforest), year of most recent fire and year of

118 cessation of frequent fires. We visualized Bray-Curtis distances based on soil chemical/physical

119 properties at each sample site with NMDS (metaMDS) in Vegan to assess differences between fungal communities in terms of soil chemical/physical properties. 
122 the FUNGuild v1.1 (Nguyen et al., 2016) Python script on an ITS OTU table rarefied to 5,000

123 sequences and with singletons removed. Only 'probable' and 'highly probable' assignments were

124 retained. To detect linear correlations between sample alpha diversity and soil chemical/physical

125 properties, we generated Shannon's diversity (entropy) values (Shannon, 1948) for all samples in

126 QIIME2 (qiime diversity alpha) and Pearson's correlation coefficient, which measures the

127 strength of a linear relationship between two variables, with rcor $r$ in the R package Hmiscv4.4-2

128 (Harrell, 2021). We used redundancy analysis (RDA) in R with the package GGORD (Beck, 129 2017) to extract and summarise the variation in response variables (sample fungal community 130 composition, individual taxa) and explanatory variables (burn status, soil chemical/physical 131 properties) based on Hellinger-transformed OTU tables to give lower weights to rare taxa. Krona 132 v2.7.1 (Ondov et al., 2011) was used to visualise the proportional taxonomic composition of 133 fungal communities.

\section{Results}

\subsection{Sequence data}

After DADA2 quality filtering in QIIME2, we retained 722,732 ITS sequences from 42 samples, which clustered into a total of 6960 fungal OTUs, from which we identified $165 \mathrm{EM}$ and 654 saprotrophic taxa.

\subsection{Soil chemistry}

141 a site had been burned $(\mathrm{P}=0.012)$ had the most influence on fungal communities (Table 2).

142 Interactions between variables were associated with differences in soil chemistry. Depth interacted

143 with burn status $(\mathrm{P}=0.001)$, vegetation type $(\mathrm{P}=0.001)$, year of cessation of frequent fires $(\mathrm{P}=$ $1440.010)$ and year of last fire $(P=0.010)$. NMDS showed that samples clustered primarily with 
145 sample depth and burn status (Figure 1). The greatest variability in soil chemistry was in outlier

146 samples from unburned mesophyll/notophyll rainforest.

Table 2 PERMANOVA of relative influence on soil chemical/physical properties of sampling depth, burn status (burned/unburned), vegetation type (shrubland, grassy woodland, regenerating closed canopy forest, semi-deciduous notophyll forest, wet rainforest), year of most recent fire and year of cessation of frequent fires. Sampling depth and burn status were important factors associated with differences in soil chemistry between sites. (Single-column fitting table.)

\begin{tabular}{lcccc} 
& $\boldsymbol{D f}$ & $\boldsymbol{F}$ model & $\boldsymbol{R}^{2}$ & $\boldsymbol{P}$ \\
\hline Depth & 1 & 26.5986 & 0.352 & $\mathbf{0 . 0 0 1}$ \\
Burn status (burned/unburned) & 1 & 6.5186 & 0.086 & $\mathbf{0 . 0 1 2}$ \\
Vegetation type & 4 & 1.0067 & 0.053 & 0.410 \\
Year of most recent fire & 2 & 0.0288 & 0.001 & 0.979 \\
Year of cessation of frequent fires & 2 & 0.0288 & 0.001 & 0.980 \\
\hline
\end{tabular}

\subsection{Fungal community diversity and effects of soil nutrient levels}

Shannon's diversity index (entropy) was higher for saprotrophic fungi than EM fungi

149 (Figure 2), particularly in the litter layer $(0-10 \mathrm{~cm})$ at unburned forest sites. Shannon's diversity 150 index of saprotrophic fungi correlated linearly with all measurements of soil physical/chemical 151 properties. Diversity of EM communities correlated only with $\mathrm{NH}_{4}$ (Table 3). In general, $\mathrm{NO}_{3}, \mathrm{P}$,

$152 \mathrm{Ca}$ and $\mathrm{pH}$ were higher in unburned than in burned sites. Increased diversity of saprotrophic fungi 153 correlated with levels of soil $\mathrm{NH}_{4}, \mathrm{NO}_{3}, \mathrm{P}, \mathrm{K}$ and $\mathrm{Ca}$, and there was a marginally significant

154 correlation with $\mathrm{pH}$. Lower diversity of EM communities at several unburned sites was associated 155 with elevated soil nutrient levels relative to burned sites, although this trend was less evident for 156 K levels (Figure 3). At unburned sites, saprotrophs were more diverse at $0-10 \mathrm{~cm}$ depth if levels 157 of $\mathrm{NO}_{3}, \mathrm{P}, \mathrm{K}$ and $\mathrm{Ca}$ were elevated. Saprotrophic diversity was more variable at $20-30 \mathrm{~cm}$ depth, 158 where nutrient levels were lower. 


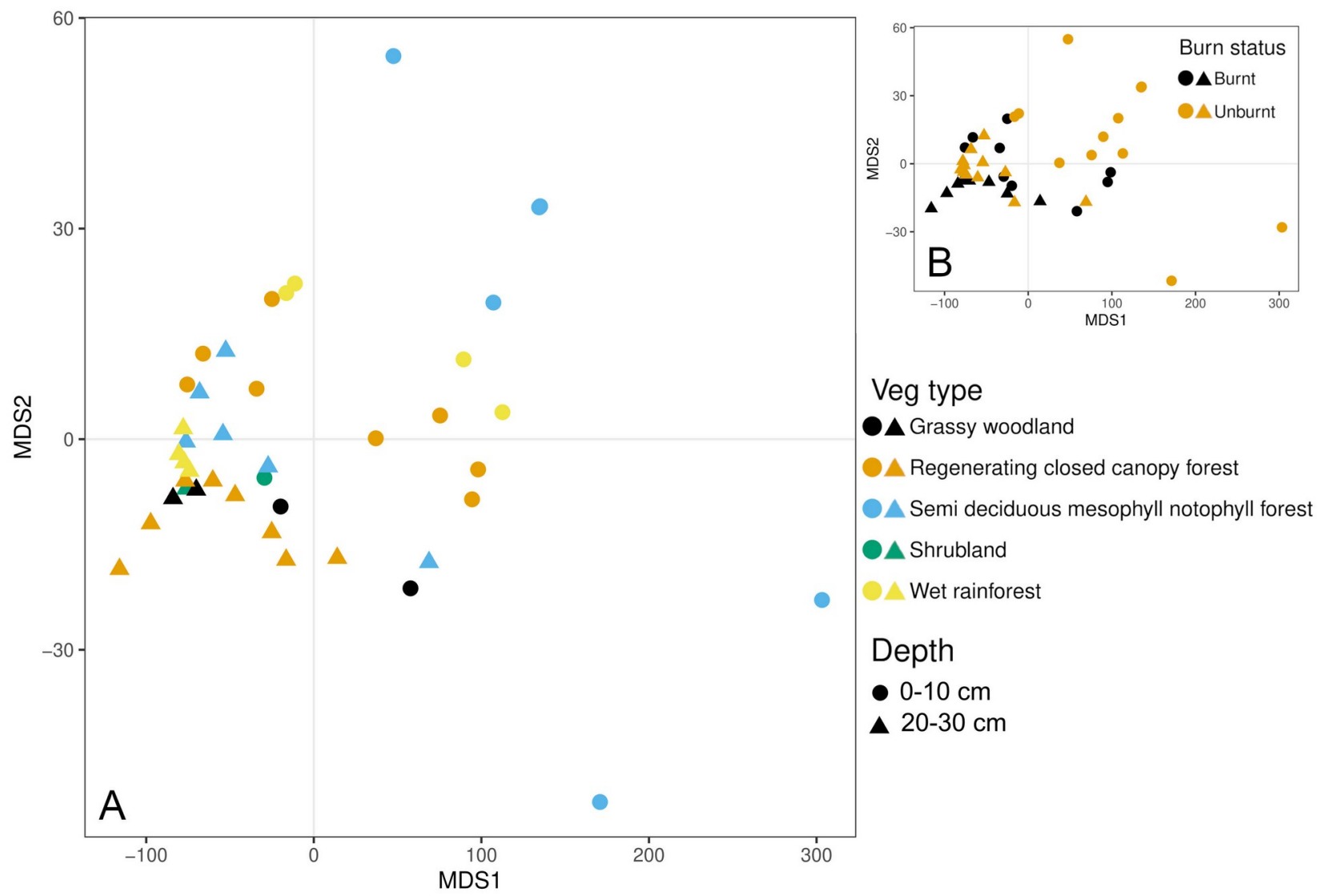

Figure 1 Non-metric multidimensional scaling showing differences between soil chemistry of samples from sites with different vegetation types and burn status (burned/unburned). Based on a Bray-Curtis distance matrix of nutrient variables for soils at each each site including ammonium $\left(\mathrm{NH}_{4}\right)$, nitrate $\left(\mathrm{NO}_{3}\right)$, phosphorus $(\mathrm{P})$, potassium $(\mathrm{K})$, organic carbon $(\mathrm{C}), \mathrm{pH}$ and calcium $(\mathrm{Ca})$. Samples clustered primarily according to sampling depth (A) and burn status (B). The greatest variability in terms of soil chemistry was in outlier samples from unburned mesophyll/notophyll rainforest. (1.5-column fitting image. Color to be used in print.)

Table 3 Pearson's correlation coefficient testing linear relationships between Shannon's diversity (entropy) of soil fungal communities and soil chemical/physical properties. $P$ values $<0.05$ indicated by bold type.

Diversity values for EM fungi correlated linearly with levels of soil $\mathrm{NH}_{4}$, but a relationship with soil chemistry was reflected more strongly in saprotroph diversity, which was highly correlated with levels of $\mathrm{NH}_{4}$ as well as with $\mathrm{NO}_{3}, \mathrm{P}, \mathrm{K}, \mathrm{Ca}$ and $\mathrm{pH}$. (Single-column fitting table.)

\section{Ectomycorrhizal}

Saprotrophic

\begin{tabular}{l|cc|cc}
\cline { 2 - 5 } & Pearson's correlation & $\mathrm{P}$ & Pearson's correlation & $\mathrm{P}$ \\
\hline Ammonium & 0.330 & $\mathbf{0 . 0 3 5}$ & 0.326 & $\mathbf{0 . 0 3 5}$ \\
Nitrate & -0.018 & 0.913 & 0.464 & $\mathbf{0 . 0 0 2}$ \\
Phosphorus & 0.041 & 0.799 & 0.422 & $\mathbf{0 . 0 0 5}$ \\
Potassium & 0.186 & 0.243 & 0.511 & $\mathbf{0 . 0 0 1}$ \\
pH level & -0.236 & 0.138 & 0.299 & 0.055 \\
Calcium & -0.137 & 0.393 & 0.388 & $\mathbf{0 . 0 1 1}$ \\
\hline
\end{tabular}




\section{Ectomycorrhizal}

Burned

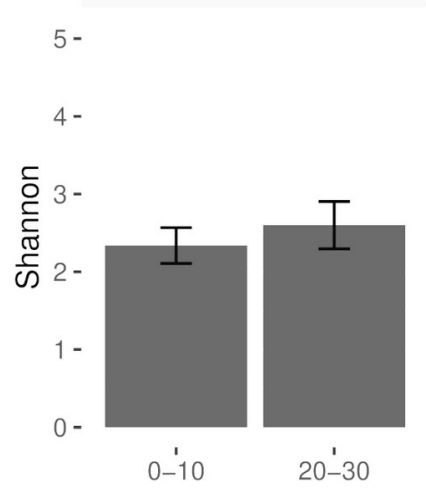

$0.6-$
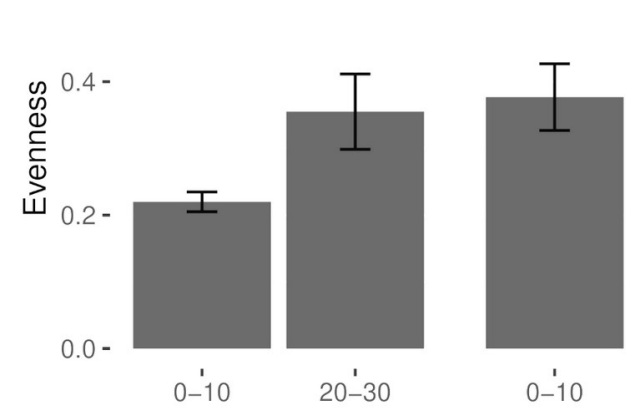

Unburned

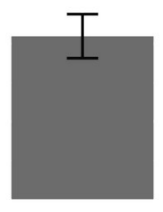

$0-10$

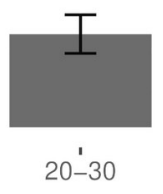

\section{Saprotrophic}

Burned

Unburned

5 -
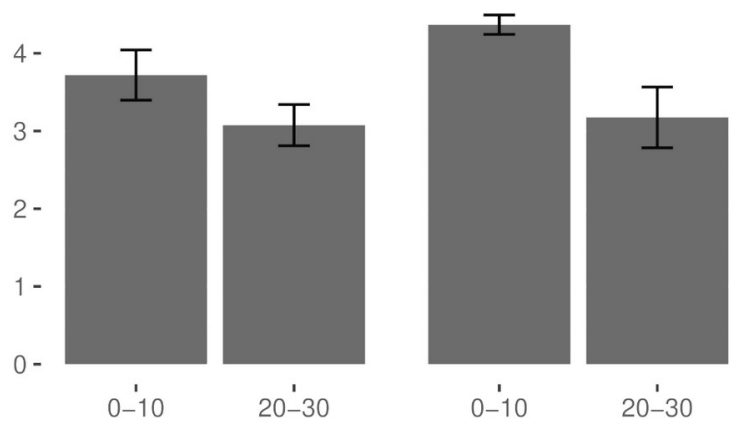

$0.6-$

$0.4-$
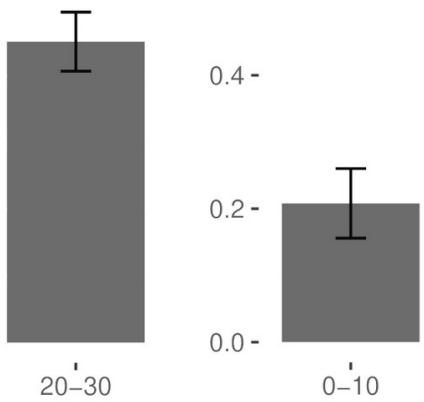

$0-10$

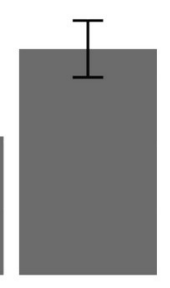

$20-30$

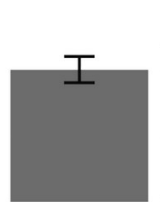

$0-10$

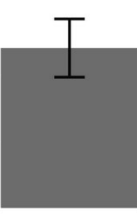

$20-30$

Sampling depth $(\mathrm{cm})$

Figure 2 Average Shannon's diversity values and Simpson's evenness (similarity of abundance between species) for EM and saprotrophic soil fungi at burned and unburned sites and at two sampling depths. Bars indicate standard error. In general, EM fungi were more diverse and less even at burned versus unburned sites, whereas saprotrophic communities were more diverse and less even at unburned sites. Average Shannon's diversity of EM fungi at unburned sites was lowest at deeper soil horizons, and EM communities at these sites had the highest average evenness values of all site types, indicating a late-successional community structure. (Single-column fitting image.)

\subsection{Fungal diversity and community structure and effects of historical burning}

Whether or not a site had been burned most influenced the community structure of saprotrophic fungi at both sampling depths, and of EM fungi at $20-30 \mathrm{~cm}$ below the soil surface

(Table 4). The number of years that had elapsed since the most recent fire had most influence on

EM community structure $0-10 \mathrm{~cm}$ below the surface $(\mathrm{P}=0.005)$. Vegetation type was the second most important factor for EM fungi at $20-30 \mathrm{~cm}(\mathrm{P}=0.011)$. Saprotrophic soil fungi at $0-10 \mathrm{~cm}$ depth were secondarily influenced by vegetation type $(\mathrm{P}=0.010)$. The influence of years since the 
167 detected between vegetation type and the number of years since the most recent fire at 20-30 cm

168 depth on the community structure of saprotrophic soil fungi $(\mathrm{P}=0.007)$.

169 EM communities had higher average Shannon's diversity indices and lower evenness at 170 burned compared to unburned sites (Figure 2). Saprotrophic communities were more diverse and 171 less even at unburned sites. Notably, the average Shannon's diversity of EM fungi at unburned 172 sites was lowest at deeper soil horizons $(20-30 \mathrm{~cm})$. EM communities at unburned sites had the 173 highest average evenness values of all site types. NMDS of fungal community dissimilarity (Bray174 Curtis) showed that samples clustered primarily according to burn status and depth (Figure 4).

175 EM communities were more like each other at burned than at unburned sites. Soil saprotrophs 176 were more similar at unburned sites than at burned sites. 


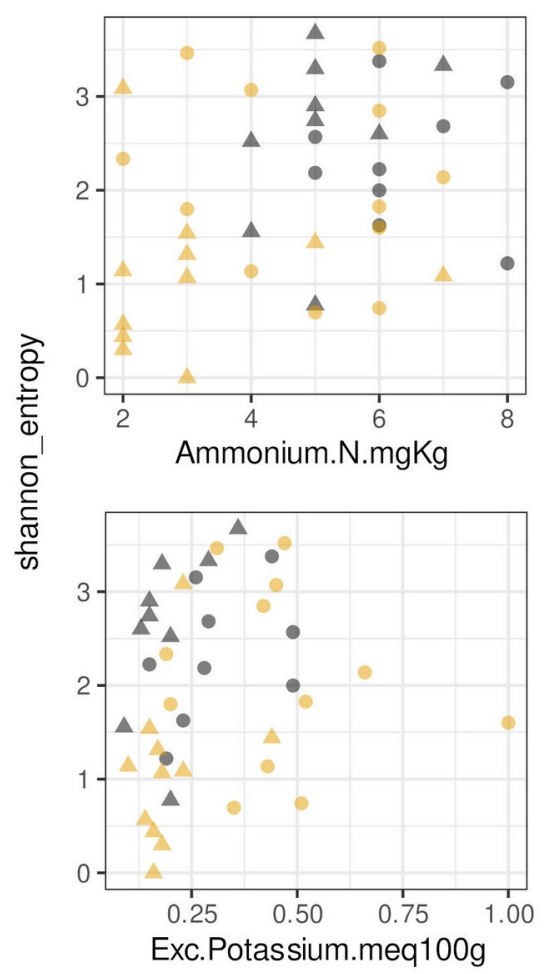

OA Burnt

Unburnt
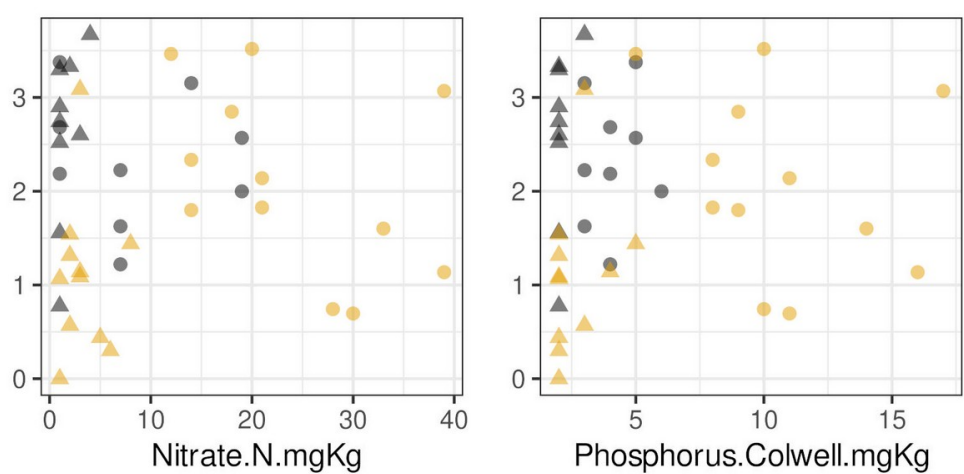

Phosphorus.Colwell.mgKg

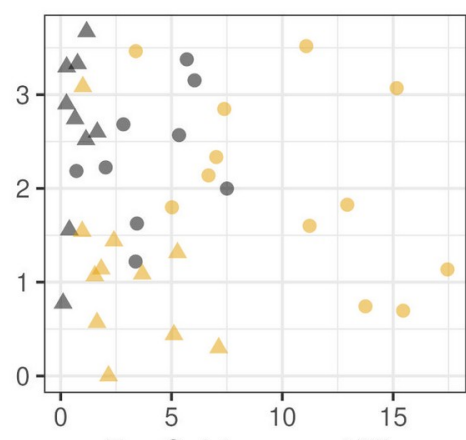

Exc.Calcium.meq100g

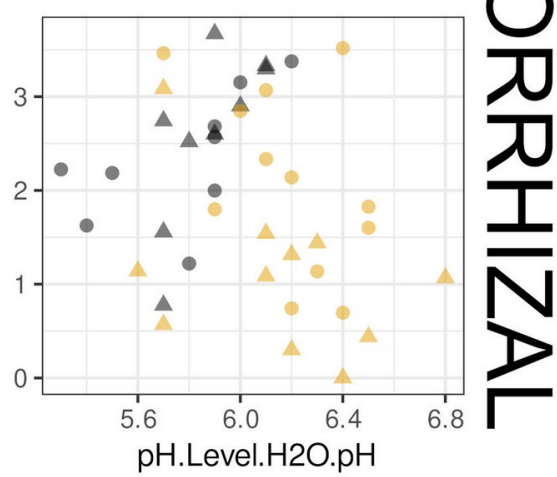

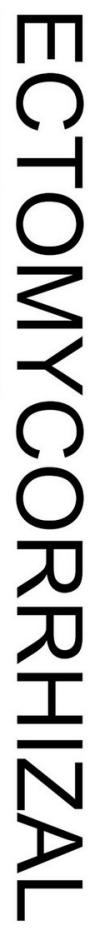

pH.Level.H2O.pH

$0-10 \mathrm{~cm}$

$20-30 \mathrm{~cm}$
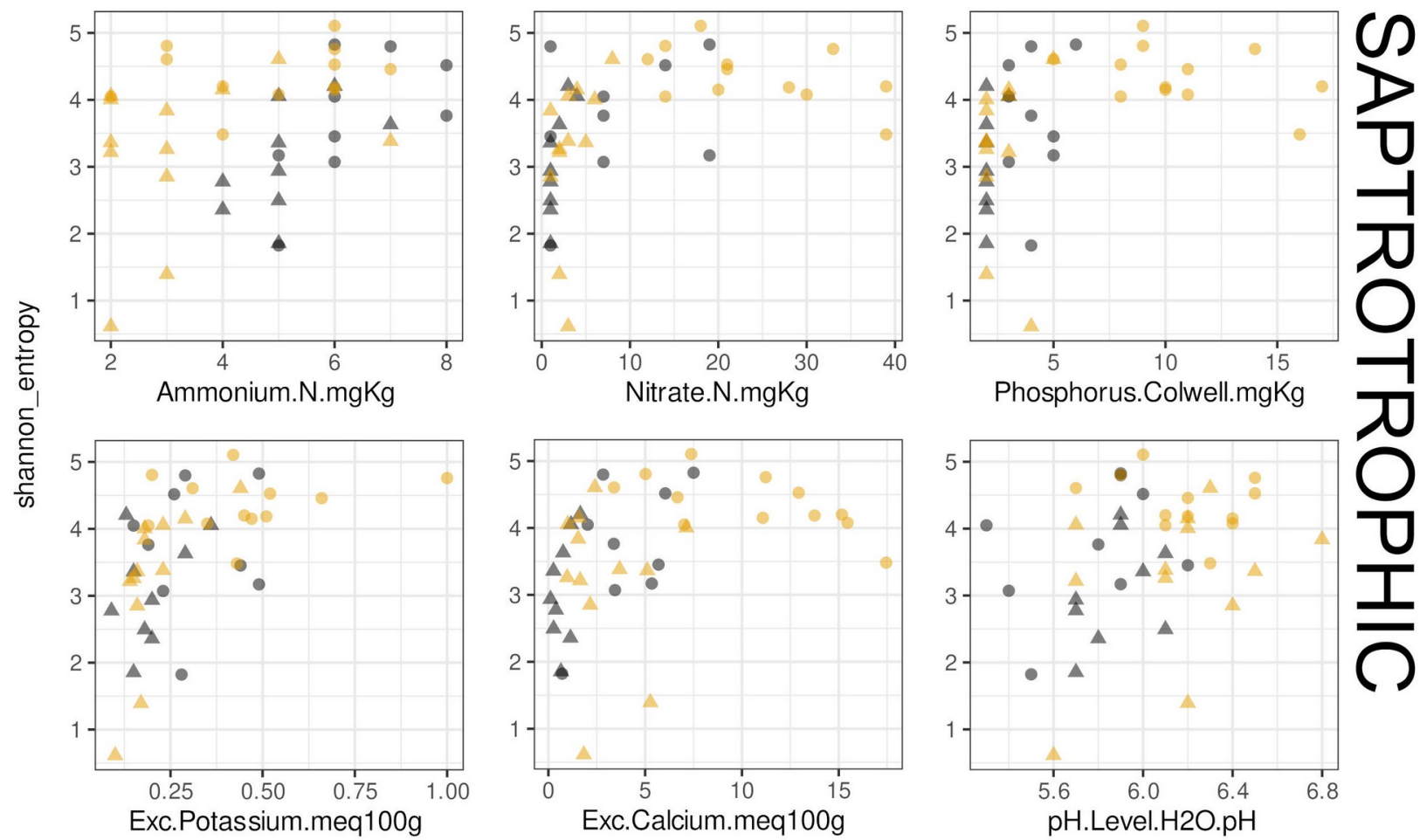

Phosphorus.Colwell.mgKg
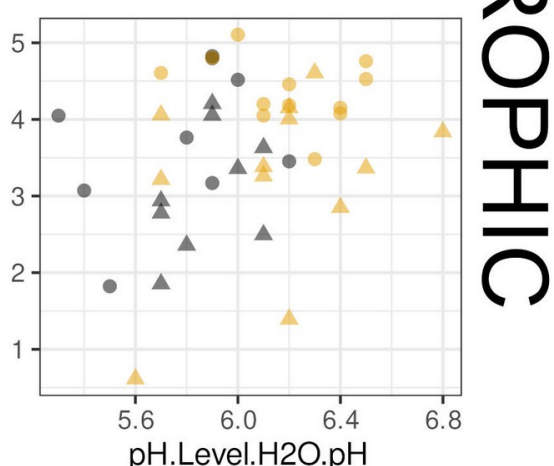

Figure 3 Shannon's diversity (entropy) for ectomycorrhizal and saprotrophic soil fungi plotted against soil physical/chemical properties (levels of $\mathrm{NO}_{3}, \mathrm{NH}_{4}, \mathrm{P}, \mathrm{K}, \mathrm{Ca} \& \mathrm{pH}$ ) at burned and unburned sites and at two sampling depths. Lower diversity of EM communities at several unburned sites was associated with elevated soil nutrient levels relative to burned sites, however this trend was less evident for $\mathrm{K}$ levels. At unburned sites, saprotrophs at $0-10 \mathrm{~cm}$ depth were more diverse if $\mathrm{NO}, \mathrm{P}, \mathrm{K}$ and $\mathrm{Ca}$ were present at elevated levels, whereas at a depth of $20-30 \mathrm{~cm}$ saprotrophic diversity was more variable and levels of those nutrients were lower. (2-column fitting image. Color to be used in print.) 
Table 4 Results of PERMANOVA testing whether the burn status of a site (burned/unburned) and vegetation type (shrubland, grassy woodland, regenerating closed canopy forest, semi-deciduous notophyll forest, wet rainforest) were associated with changes in the community composition of ectomycorrhizal and saprotrophic soil fungi. Depth of sampling was a primary influence on community composition of EM $(P=0.019)$ and saprotrophic $(P=0.045)$ fungi, and datasets were split according to depth. All sites were included in the first analysis, as well as interactions between factors. Influence of years since most recent fire, years since cessation of frequent fires and interactions with vegetation type were subsequently analysed for burned sites only. $\mathrm{P}$ values $<0.05$ are shown in bold type. (2-column fitting table.)

\begin{tabular}{|c|c|c|c|c|c|}
\hline & Depth (cm) & Factor & F model & $R^{2}$ & $\boldsymbol{P}$ \\
\hline \multirow{12}{*}{ 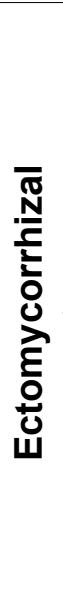 } & \multirow{6}{*}{$0-10$} & Years since most recent fire & 1.93 & 0.22 & 0.005 \\
\hline & & Burn status & 1.32 & 0.07 & 0.046 \\
\hline & & Veg type & 0.81 & 0.17 & 0.635 \\
\hline & & Burn status:Veg type & 0.73 & 0.20 & 0.797 \\
\hline & & Years since cessation of frequent fires & 1.19 & 0.15 & 0.177 \\
\hline & & Years since most recent fire:Veg type & 0.93 & 0.24 & 0.512 \\
\hline & \multirow{6}{*}{$20-30$} & Burn status & 1.37 & 0.07 & 0.007 \\
\hline & & Veg type & 4.26 & 0.52 & 0.011 \\
\hline & & Burn status:Veg type & 3.32 & 0.53 & 0.019 \\
\hline & & Years since most recent fire & 1.01 & 0.13 & 0.552 \\
\hline & & Years since cessation of frequent fires & 0.77 & 0.10 & 0.505 \\
\hline & & Years since cessation of frequent fires: Veg type & 5.99 & 0.67 & 0.027 \\
\hline \multirow{12}{*}{$\begin{array}{l}\frac{0}{\frac{1}{2}} \\
\frac{0}{0} \\
\frac{0}{2} \\
\frac{0}{0} \\
\frac{0}{d} \\
\text { ஸे }\end{array}$} & \multirow{6}{*}{$0-10$} & Burn status & 1.67 & 0.08 & 0.004 \\
\hline & & Veg type & 2.19 & 0.35 & 0.010 \\
\hline & & Burn status:Veg type & 1.80 & 0.37 & 0.031 \\
\hline & & Years since most recent fire & 1.01 & 0.13 & 0.549 \\
\hline & & Years since cessation of frequent fires & 0.95 & 0.12 & 0.507 \\
\hline & & Years since cessation of frequent fires: Veg type & 2.06 & 0.41 & 0.086 \\
\hline & \multirow{6}{*}{$20-30$} & Burn status & 1.39 & 0.07 & 0.046 \\
\hline & & Veg type & 1.22 & 0.23 & 0.164 \\
\hline & & Burn status:Veg type & 1.01 & 0.25 & 0.239 \\
\hline & & Years since most recent fire & 3.28 & 0.32 & 0.080 \\
\hline & & Years since cessation of frequent fires & 1.10 & 0.14 & 0.299 \\
\hline & & Years since most recent fire:Veg type & 5.22 & 0.63 & 0.007 \\
\hline
\end{tabular}

\subsection{Abundance of specific fungal taxa at sites with constrasting nutrient profiles}

179 nutrients (Figure 5). Russula ${ }^{3}$, Pezizaceae, Pyronemataceae and Agaricales $^{5,6}$ were present in

180 higher abundance in soil with elevated levels of N, P, K and Ca. Entoloma and Tomentella were

181 associated with elevated $\mathrm{pH}$, whereas Sebacina, Chloridium and Thelephoraceae 1 were

182 associated with lower $\mathrm{pH}$. Saprotrophic taxa associated with elevated N, P, K and Ca included

183 Bionectria, Leohumicola and Archaeorhizomyces 6. Lower levels of these nutrients were 
185 the saprotrophic taxa Clavaria, Idriella and Phallaceae, and lower $\mathrm{pH}$ with Hygrocybe,
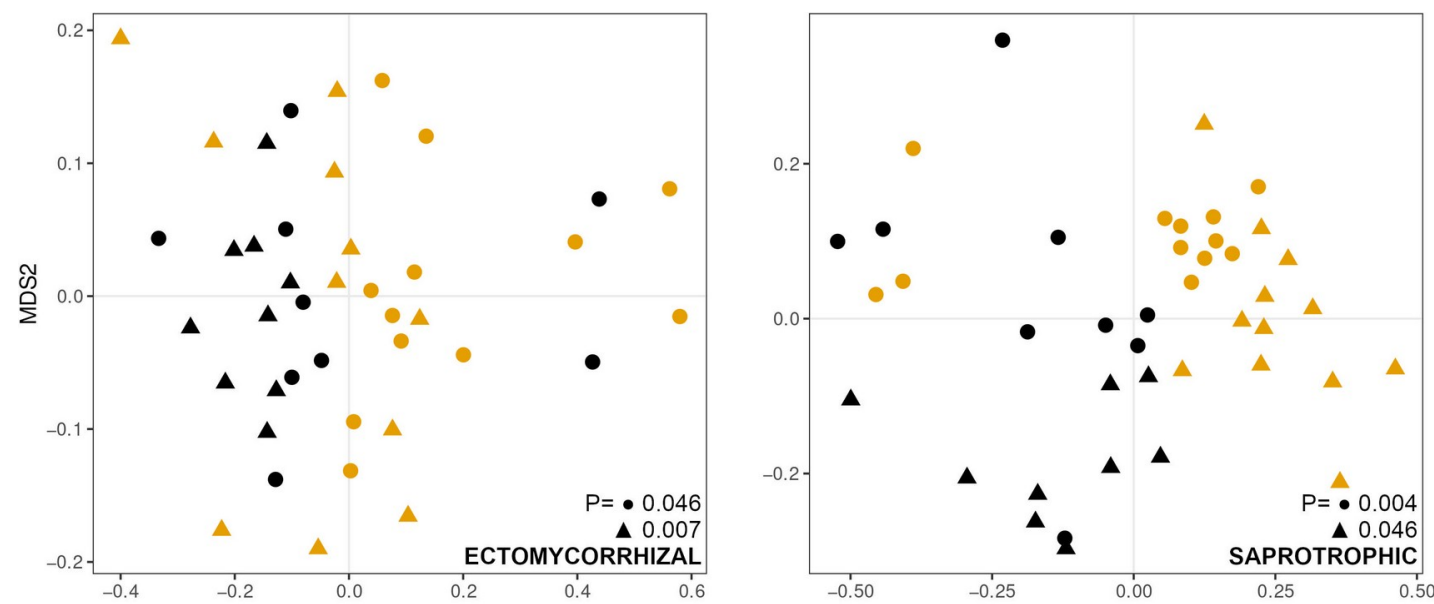

Burnt

- $0-10 \mathrm{~cm}$

MDS1

\section{Unburnt}

A $20-30 \mathrm{~cm}$

Figure 4 Non-metric multidimensional scaling showing differences in fungal community composition between burned and unburned sites at two sampling depths for ectomycorrhizal and saprotrophic fungi. Matrix based on Bray-Curtis distances. $P$ values refer to PERMANOVA test for significance in differences in taxonomic community structure between burned and unburned sites at each sampling depth. Samples clustered primarily according to burn status and depth. EM communities were more similar to each other at burned over unburned sites. Soil saprotrophs were more similar at unburned sites than at burned sites. (Single-column fitting image. Color to be used in print.)
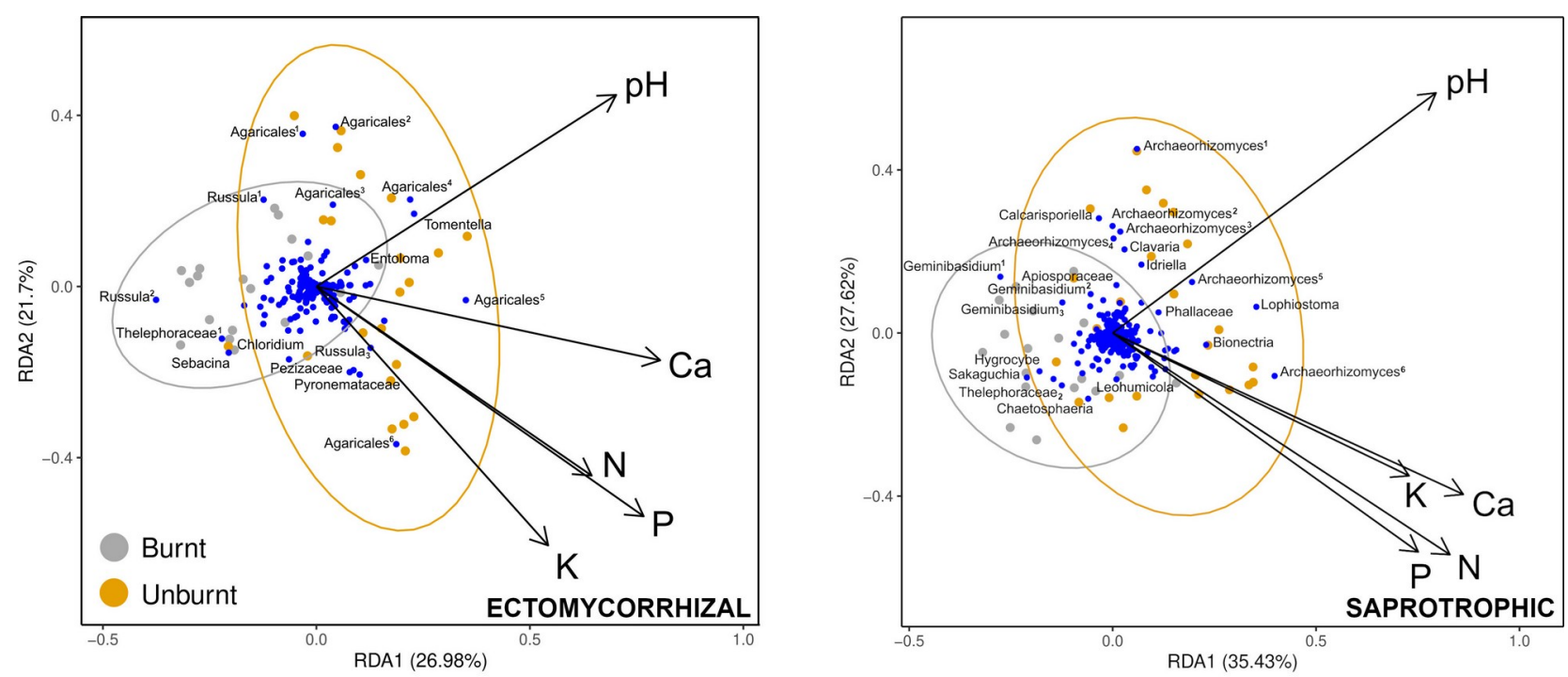

Figure 5 Redundancy analysis (RDA) summarising variation in response variables (fungal community composition and individual taxa) and explanatory variables (soil chemical/physical properties) at burned and unburned sites. Blue dots represent individual fungal operational taxonomic units. Taxon and site dots appearing closer to arrow tips were associated with higher levels of that soil chemical/physical variable, whereas taxon and site dots appearing opposite to an arrow were associated with lower levels. An angle of 90 degrees indicates little or no correlation. Based on Hellinger-transformed OTU tables to give lower weights to rare taxa. (2-column fitting image. Color to be used in print.) 
187

188

189

190

191

192

193

194

195

196

197

198

199

200

201

202

\subsection{Abundance of specific fungal taxa at sites with constrasting fire histories}

We assigned ecological guild and trophic mode for 165 EM and 654 saprotrophic soil taxa from 1,696 assigned OTUs with FUNGuild v1.1 (Nguyen et al., 2016). The basidiomycete taxa Russula, Hemileccinium, Lactifluus, Amanita, Mycosymbioces and Thelephoraceae were dominant at unburned sites and sites burned prior to 2015 (Figure 6). Ascomycota were present in increased abundance and taxonomic diversity, including Meliniomyces and the truffle taxon Ruhlandiella, at sites burned immediately prior to sampling in 2017. Species richness of EM fungi decreased linearly from the time of last fire, from 72 OTUs at unburned sites to 12 at sites burned in 2014. The exceptions to this trend were sites that were most recently burned, which had 58 EM OTUs. Species richness was at least twofold higher for saprotrophs over EM at all sites, and up to 6 times higher at unburned sites (Figure 6). Unburned sites were dominated by Archaeorhizomyces (Ascomycota) and Hygrocybe (Basidiomycota). Dominant saprotrophic taxa at burned sites included Geminibasidium, Hygrocybe, Thelephoraceae (Basidiomycota) and Umbelopsis and Mycosymbioces (Ascomycota). A similar trend of decreased species richness from the time of last fire was also evident for saprotrophs, from 465 OTUs at unburned sites to 31 at sites burned in 2014, with 145 OTUs at sites that were most recently burned.

Figure 6 (following page) Taxonomic composition and abundance of ectomycorrhizal (EM) and saprotrophic soil fungi at sites with different fire histories. Numbers inside circles in grey represent numbers of OTUs detected (species richness). Species richness of EM fungi decreased linearly from the time of last fire, from 72 OTUs at unburned sites to 12 at sites burned in 2014. (2-column fitting image. Color to be used in print.) 
bioRxiv preprint doi: https://doi.org/10.1101/2021.08.22.457293; this version posted August 23, 2021. The copyright holder for this preprint (which was not certified by peer review) is the author/funder. All rights reserved. No reuse allowed without permission.

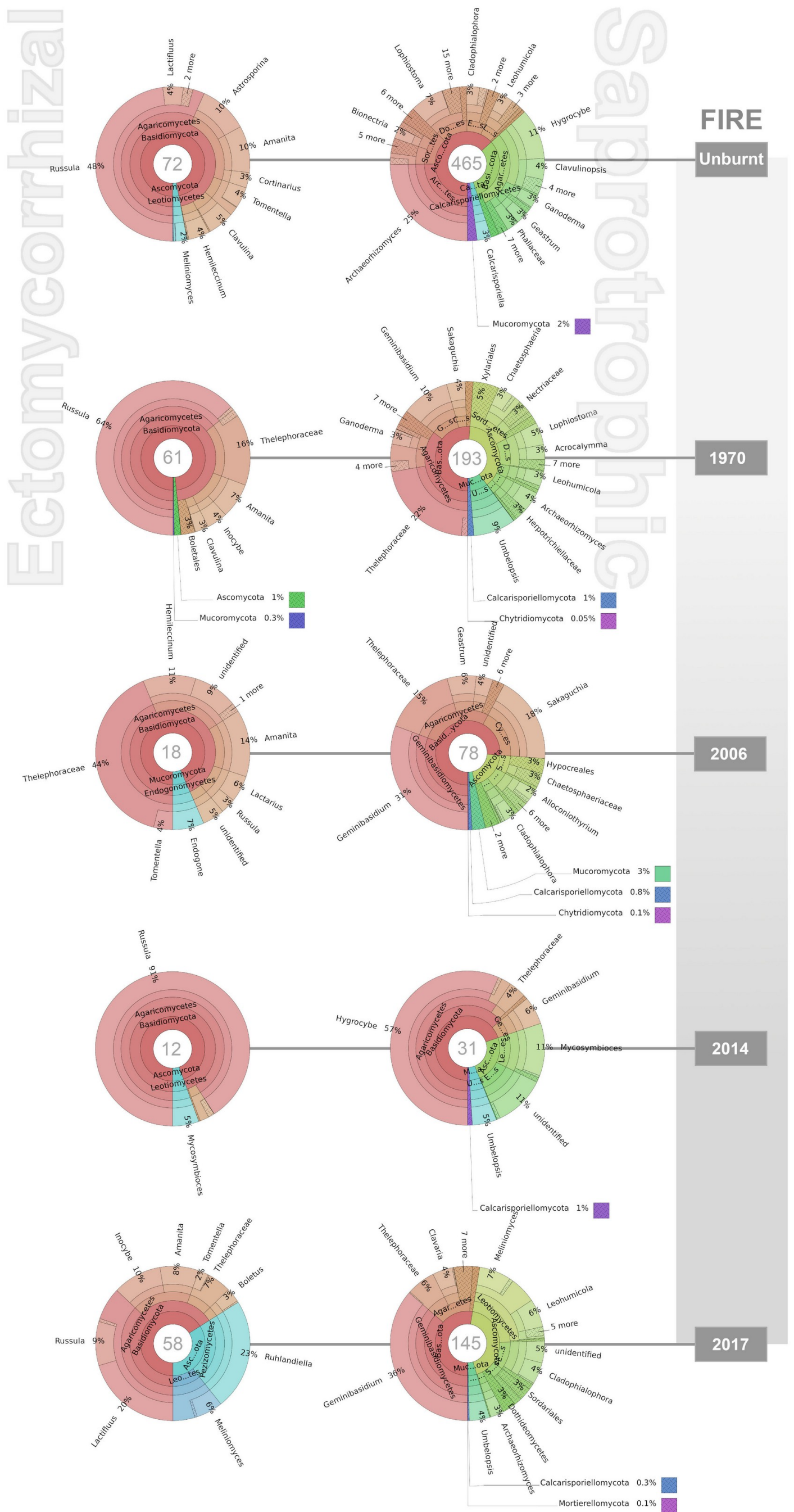




\section{Discussion}

Saprotrophic and EM fungi showed major community-level changes in response to fire,

205

206

207

208

209

which interacted with and modified these functional guilds in different ways. Fire induced compositional changes in the dominant vegetation, which altered EM composition through the replacement of mycorrhizal hosts. The changes to EM composition were largely independent of alterations to soil chemistry. By contrast, the community composition, diversity and evenness of saprotrophic fungi changed after fire in response to reduced soil nutrient levels. We also detected fire-dependent shifts in the composition of saprotrophic fungi in litter at shallow soil horizons.

\subsection{Fire impacts ectomycorrhizal fungi by changing plant communities}

EM fungi are important tree symbionts in forest ecosystems. The taxonomic community composition and abundance of EM fungi differed between burned and unburned forest soils. EM fungi were strongly influenced by the dominant vegetation. In general, EM communities were less diverse and more even at unburned sites, which indicated a late-successional community structure dominated by a small number of taxa including Russula and Amanita. Successional shifts, in which EM community composition progresses from post-fire tree stand initiation to canopy closure, are well-documented (LeDuc et al., 2013; Longo et al., 2011).

The more recently a site had been burned, the lower the species richness of EM fungi, which was congruent with reports from temperate forests in the Northern Hemisphere (Kipfer et al., 2011; LeDuc et al., 2013; Rincón et al., 2014). An increase in EM species richness at sites burned immediately prior to sampling contrasts with other studies that showed immediate negative effects of fire on EM diversity. One explanation may be that ascomycete EM taxa were more diverse and abundant at burned sites relative to unburned sites. If fire had occurred the year prior to sampling, Ruhlandiella (hypogeous fungi, or truffles), which are dispersed primarily by mycophagous mammals (Claridge, 2002; Dundas et al., 2018), were the most abundant of this pyrophilic group. Ruhlandiella are known to fruit abundantly after bushfires (Kraisitudomsook et 
al., 2019; Warcup, 1990). Reduction of undergrowth by fire also has the potential to increase

229

230

231

232

233

234

235

236

237

238

239

240

241

242

243

244

245

246

247

248

249

250

251

252 mammalian access to the soil, which increases foraging and dispersal activity. Increased activity of pyrophilic taxa such as Ruhlandiella and those dispersed by mycophagous mammals may explain the short-term, post-fire increase in EM diversity.

\subsection{Saprotrophic fungi are impacted by fire-driven nutrient shifts}

This study showed that forest fire alters the structure of saprotrophic communities primarily by changing nutrient levels in the soil and by altering the composition of the litter layer through changes in plant community composition. Saprotrophic fungi were more diverse and less even at unburned sites, where levels of soil nutrients were higher. Unlike EM fungi, saprotroph diversity was influenced by levels of all soil nutrients measured, including a weak yet measurable influence of $\mathrm{pH}$. Strong positive correlations between diversity of saprotrophic fungi and the soil quality indicators $\mathrm{N}, \mathrm{P}$ and $\mathrm{NH}_{4}$ have been reported (Chen et al., 2021), as well as increases in saprotrophic biomass and diversity in response to experimental addition of $\mathrm{N}$ to soils (Clocchiatti et al., 2020). In a global study, Ca was found to be the strongest predictor of soil fungal diversity (Tedersoo et al., 2014). In this study in the AMT, we found $\mathrm{Ca}, \mathrm{NO}_{3}, \mathrm{P}$ and $\mathrm{K}$ were strongly correlated with saprotroph diversity.

Soil saprotrophs showed marked changes in species richness in response to fire. In recently-burned areas, the species richness of soil saprotrophs was almost double that measured at most other burned sites. Fungal saprotrophs were dominated by Geminibasidium (Basidiomycota) and Meliniomyces (Ascomycota) in recently burned areas. We found higher species richness and Shannon's diversity of saprotrophic over EM fungi regardless of a site's fire history. Salo et al. (2019) described an increase in saprotrophic fungal diversity immediately after fire, with saprotrophic succession in soil more rapid than in wood. In Australian Mountain Ash forests, distinctive communities of soil fungi appeared in the year after fire disturbance, followed by much longer seral phases dominated by non-pyrophilic species (McMullan-Fisher et al., 2002). As 
outlined by Verma and Jayakumar (2012), low-intensity fires in 2017 may have increased the

254

255

256

257

258

259

260

261

262

263

264

265

266

267

268

269

270

271

272

273

274

275

276

277

amount of organic material available, leading to a rise in saprotrophic diversity.

The dominant vegetation type shaped saprotrophic communities in the litter soil horizon, which indicated that certain types of organic litter may favour some fungal taxa over others. Wu et al. (2011) found that leaf type was one of the main drivers of fungal community biomass and composition. Lunghini et al. (2013) reported higher fungal diversity in mixed litter than in monospecific litter. We propose that fire-induced alterations to plant community composition lead to compositional changes in the litter layer, which in turn select for particular communities of saprotrophic fungi.

\subsection{Soil chemistry was altered by fire}

Soil chemistry in the Iron Range has been altered by fire. Chemical/physical properties differed between burned and unburned sites and between the litter and mineral soil layers, with $\mathrm{NO}_{3}, \mathrm{P}, \mathrm{Ca}$ and $\mathrm{pH}$ generally higher in unburned than at burned sites. This is congruent with current knowledge of fire-nutrient dynamics in tropical forests, where soil nutrients are depleted by recurrent fires (Bowman, 2009a). Conversely, occasional fires can cause a short-term increase in nutrient availability at shallow soil horizons via combustion of litter and soil organic matter. Low wind and high sub-canopy moisture generate fires of lower intensity in AMT forests than in savannas (Cochrane, 2003; Verma and Jayakumar, 2012). Vegetation changes can influence levels of soil nutrients, especially N (Evans et al., 2001; Zhou et al., 2018). We found a greater net effect of burning on soil chemical/physical properties, with no discernible patterns attributable to the different vegetation types studied. This suggests that alteration of nutrient profiles by fire has been direct, most likely through volatilization of litter and soil organic matter (Verma et al., 2019), rather than by indirect alterations to plant community composition.

We detected a strong correlation between levels of soil $\mathrm{NH}_{4}$ and the diversity of EM fungi.

There was no correlation between EM diversity and other soil chemical/physical properties 
measured in this study. We propose that host availability and fire have a greater influence over rainforest EM community composition than levels of soil $\mathrm{NO}_{3}, \mathrm{P}, \mathrm{K}, \mathrm{C}, \mathrm{Ca}$ and $\mathrm{pH}$.

\subsection{Different fungi at different depths}

litter layer, which is expected given the affiliation of EM fungi with tree roots. Primary notophyll

rainforest in other areas of North Queensland has higher root biomass and root length compared to opportunity for EM colonisation of compatible hosts.

\section{Conclusions}

We support the hypothesis that tropical soil fungi are impacted by burning, which altered the abundance and phylogenetic structure of EM and saproptrophic communities in different ways. Communities of EM fungi were structurally altered by fire through vegetation changes at burned and unburned sites. Truffle-like taxa that are reliant on mycophagous mammals were more abundant at recently burned sites. In general, EM fungi at unburned sites had a late-successional higher and less even than at unburned sites. The diversity of saprotrophic fungi was impacted by reduced soil chemical/physical levels after fire. In the litter layer, the community composition of saprotrophs was influenced by changes in vegetation type. removed an estimated $32 \%$ of anthropogenic $\mathrm{CO} 2$ emissions from the atmosphere (Le Quéré et

300 al., 2018). Of these terrestrial sinks, tropical forests are some the largest due to their rapid growth 301 (Keenan and Williams, 2018). Large savanna-dominated areas of Australia's tropical north could, 
302 if protected from burning, support tropical forestry for carbon sequestration (K. Cook, pers.

303 comm.), which may become a serious option for Australia as states begin to commit to net zero

304 emissions (NSWDPIA, 2020). Any assessment of native tropical tree species for their utility in 305 carbon forestry should consider their mycorrhizal symbionts and their tractability for the 306 production of inoculum. Australia's tropical fungi have the potential to serve as a major biological 307 resource over the approaching decades.

\section{CRediT authorship contribution statement}

309 Jed Calvert: Conceptualization, Methodology, Formal analysis, Investigation, Writing - Original

310 Draft, Visualization, Project administration. Alistair McTaggart: Conceptualization,

311 Methodology, Writing - Review \& Editing, Supervision. Lília C. Carvalhais: Methodology,

312 Formal analysis, Writing - Review \& Editing. André Drenth: Writing - Review \& Editing,

313 Supervision. Roger Shivas: Writing - Review \& Editing, Supervision.

\section{Role of the funding source}

315 Keith Cook and the Maxim Foundation provided financial support for the conduct of this research

316 and provided initial ideas for the study design as well as assistance in the collection of data. The

317 funding source had no role in the analysis and interpretation of data, the writing of the report, or in

318 the decision to submit the article for publication.

\section{Research data for this article}

320 The dataset and metadata supporting this article is available in the BioPlatforms Australia 321 project's data portal under the sample accessions 42144-42185 (https://ccgapps.com.au/bpametadata/base), doi:10.4227/71/ 561c9bc670099. 


\section{Declaration of competing interest}

324

325

326

327

328

329

The authors declare that they have no known competing financial interests or personal relationships that could have appeared to influence the work reported in this paper.

\section{Acknowledgements}

The authors would like to acknowledge the Maxim Foundation for financial support for the project. We would also like to express our gratitude to Sofi Houghton for her design of the graphical abstract.

\section{References}

Abarenkov, K., Henrik Nilsson, R., Larsson, K.-H., Alexander, I.J., Eberhardt, U., Erland, S., Høiland, K., Kjøller, R., Larsson, E., Pennanen, T., Sen, R., Taylor, A.F.S., Tedersoo, L., Ursing, B.M., Vrålstad, T., Liimatainen, K., Peintner, U., Kõljalg, U., 2010. The UNITE database for molecular identification of fungi - recent updates and future perspectives. New Phytol. 186, 281-285. https://doi.org/10.1111/j.1469-8137.2009.03160.x

Alem, D., Dejene, T., Oria-de-Rueda, J.A., Geml, J., Castaño, C., Smith, J.E., Martín-Pinto, P., 2020. Soil fungal communities and succession following wildfire in Ethiopian dry Afromontane forests, a highly diverse underexplored ecosystem. For. Ecol. Manage. 474, 118328. https://doi.org/10.1016/j.foreco.2020.118328

Baldrian, P., 2019. The known and the unknown in soil microbial ecology. FEMS Microbiol. Ecol. 95, 1-9. https://doi.org/10.1093/femsec/fiz005

Beck, M., 2017. ggord: Ordination Plots with ggplot2.

Bengtsson-Palme, J., Ryberg, M., Hartmann, M., Branco, S., Wang, Z., Godhe, A., De Wit, P., Sánchez-García, M., Ebersberger, I., de Sousa, F., Amend, A.S., Jumpponen, A., Unterseher, M., Kristiansson, E., Abarenkov, K., Bertrand, Y.J.K., Sanli, K., Eriksson, K.M., Vik, U., Veldre, V., Nilsson, R.H., 2013. Improved software detection and extraction of ITS1 and ITS2 from ribosomal ITS sequences of fungi and other eukaryotes for analysis of environmental sequencing data. Methods Ecol. Evol. 4, n/a-n/a. https://doi.org/10.1111/2041210X.12073

Bissett, A., Fitzgerald, A., Meintjes, T., Mele, P.M., Reith, F., Dennis, P.G., Breed, M.F., Brown, B., Brown, M. V., Brugger, J., Byrne, M., Caddy-Retalic, S., Carmody, B., Coates, D.J., Correa, C., Ferrari, B.C., Gupta, V.V.S.R., Hamonts, K., Haslem, A., Hugenholtz, P., Karan, M., Koval, J., Lowe, A.J., Macdonald, S., McGrath, L., Martin, D., Morgan, M., North, K.I., 
Paungfoo-Lonhienne, C., Pendall, E., Phillips, L., Pirzl, R., Powell, J.R., Ragan, M.A., Schmidt, S., Seymour, N., Snape, I., Stephen, J.R., Stevens, M., Tinning, M., Williams, K., Yeoh, Y.K., Zammit, C.M., Young, A., 2016. Introducing BASE: The Biomes of Australian Soil Environments soil microbial diversity database. Gigascience 5. https://doi.org/10.1186/s13742-016-0126-5

Bolyen, E., Rideout, J.R., Dillon, M.R., Bokulich, N.A., Abnet, C., Al-Ghalith, G.A., Alexander, H., Alm, E.J., Arumugam, M., Asnicar, F., Bai, Y., Bisanz, J.E., Bittinger, K., Brejnrod, A., Brislawn, C.J., Brown, C.T., Callahan, B.J., Caraballo-Rodríguez, A.M., Chase, J., Cope, E., Silva, R. Da, Dorrestein, P.C., Douglas, G.M., Durall, D.M., Duvallet, C., Edwardson, C.F., Ernst, M., Estaki, M., Fouquier, J., Gauglitz, J.M., Gibson, D.L., Gonzalez, A., Gorlick, K., Guo, J., Hillmann, B., Holmes, S., Holste, H., Huttenhower, C., Huttley, G., Janssen, S., Jarmusch, A.K., Jiang, L., Kaehler, B., Kang, K. Bin, Keefe, C.R., Keim, P., Kelley, S.T., Knights, D., Koester, I., Kosciolek, T., Kreps, J., Langille, M.G., Lee, J., Ley, R., Liu, Y.-X., Loftfield, E., Lozupone, C., Maher, M., Marotz, C., Martin, B.D., McDonald, D., McIver, L.J., Melnik, A. V, Metcalf, J.L., Morgan, S.C., Morton, J., Naimey, A.T., Navas-Molina, J.A., Nothias, L.F., Orchanian, S.B., Pearson, T., Peoples, S.L., Petras, D., Preuss, M.L., Pruesse, E., Rasmussen, L.B., Rivers, A., Michael S Robeson, I., Rosenthal, P., Segata, N., Shaffer, M., Shiffer, A., Sinha, R., Song, S.J., Spear, J.R., Swafford, A.D., Thompson, L.R., Torres, P.J., Trinh, P., Tripathi, A., Turnbaugh, P.J., Ul-Hasan, S., Hooft, J.J. van der, Vargas, F., Vázquez-Baeza, Y., Vogtmann, E., Hippel, M. von, Walters, W., Wan, Y., Wang, M., Warren, J., Weber, K.C., Williamson, C.H., Willis, A.D., Xu, Z.Z., Zaneveld, J.R., Zhang, Y., Knight, R., Caporaso, J.G., 2018. QIIME 2: Reproducible, interactive, scalable, and extensible microbiome data science. https://doi.org/10.7287/peerj.preprints.27295v1

Bowman, D., 2009. The fire theory II. Fire, nutrient cycling, and topography. Aust. Rainforests 185-195. https://doi.org/10.1017/cbo9780511583490.010

Bowman, D., Brown, G., Braby, M., Brown, J., Cook, L., Crisp, M., Ford, F., Haberle, S., Hughes, J., Isagi, Y., Joseph, L., McBride, J., Nelson, G., Ladiges, P., 2010. Biogeography of the Australian monsoon tropics. J. Biogeogr. 37, 201-216.

Bowman, D.M.J.S., 2009. The fire theory IV. Aboriginal landscape burning, Australian Rainforests. https://doi.org/10.1017/cbo9780511583490.012

Bray, J.R., Curtis, J.T., 1957. An Ordination of the Upland Forest Communities of Southern Wisconsin. Ecol. Monogr. 27, 325-349. https://doi.org/10.2307/1942268

Certini, G., Moya, D., Lucas-Borja, M.E., Mastrolonardo, G., 2021. The impact of fire on soildwelling biota: A review. For. Ecol. Manage. 488, 118989. https://doi.org/10.1016/j.foreco.2021.118989

Chen, L., Xiang, W., Ouyang, S., Wu, H., Xia, Q., Ma, J., Zeng, Y., Lei, P., Xiao, W., Li, S., Kuzyakov, Y., 2021. Tight coupling of fungal community composition with soil quality in a Chinese fir plantation chronosequence. L. Degrad. Dev. 32, 1164-1178. https://doi.org/10.1002/ldr.3771 
393

394

395

396

397

398

399

400

401

402

403

404

405

406

407

408

409

410

411

412

413

414

415

416

417

418

419

420

421

422

423

424

425

426

427

428

429

430

Claridge, A.W., 2002. Ecological role of hypogeous ectomycorrhizal fungi in Australian forests and woodlands Author ( s ): Andrew W . Claridge Source: Plant and Soil , July ( I ) 2002 , Vol . 244 , No . $1 / 2$, DIVERSITY AND INTEGRATION IN MYCORRHIZAS ( Proceedings of the 3rd 244, 291-305.

Clocchiatti, A., Hannula, S.E., van den Berg, M., Korthals, G., de Boer, W., 2020. The hidden potential of saprotrophic fungi in arable soil: Patterns of short-term stimulation by organic amendments. Appl. Soil Ecol. 147, 103434. https://doi.org/10.1016/j.apsoil.2019.103434

Cochrane, M., 2003. Fire science for rainforests. Nature 421, 913-919. https://doi.org/10.1038/nature01437

Cole, L.E.S., Bhagwat, S.A., Willis, K.J., 2014. Recovery and resilience of tropical forests after disturbance. Nat. Commun. 5, 1-7. https://doi.org/10.1038/ncomms4906

Cook, K., 2020. Potential for tropical carbon forestry in the Australian Monsoon Tropics, Personal communication.

Crowther, T.W., Todd-Brown, K.E.O., Rowe, C.W., Wieder, W.R., Carey, J.C., MacHmuller, M.B., Snoek, B.L., Fang, S., Zhou, G., Allison, S.D., Blair, J.M., Bridgham, S.D., Burton, A.J., Carrillo, Y., Reich, P.B., Clark, J.S., Classen, A.T., Dijkstra, F.A., Elberling, B., Emmett, B.A., Estiarte, M., Frey, S.D., Guo, J., Harte, J., Jiang, L., Johnson, B.R., Kroël-Dulay, G., Larsen, K.S., Laudon, H., Lavallee, J.M., Luo, Y., Lupascu, M., Ma, L.N., Marhan, S., Michelsen, A., Mohan, J., Niu, S., Pendall, E., Peñuelas, J., Pfeifer-Meister, L., Poll, C., Reinsch, S., Reynolds, L.L., Schmidt, I.K., Sistla, S., Sokol, N.W., Templer, P.H., Treseder, K.K., Welker, J.M., Bradford, M.A., 2016. Quantifying global soil carbon losses in response to warming. Nature 540, 104-108. https://doi.org/10.1038/nature20150

Decaëns, T., Ecology, S.G., May, N., 2010. Macroecological patterns in soil communities Linked references are available on JSTOR for this article: Macroecological patterns in soil communities. Glob. Ecol. Biogeogr. 19, 287-302.

Dundas, S.J., Hopkins, A.J.M., Ruthrof, K.X., Tay, N.E., Burgess, T.I., Hardy, G.E.S.J., Fleming, P.A., 2018. Digging mammals contribute to rhizosphere fungal community composition and seedling growth. Biodivers. Conserv. 27, 3071-3086. https://doi.org/10.1007/s10531-018$1575-1$

Ettema, C.H., Wardle, D.A., 2002. Spatial soil ecology. Trends Ecol. Evol. https://doi.org/10.1016/S0169-5347(02)02496-5

Evans, R., Rimer, R., Sperry, L., Belnap, J., 2001. Exotic Plant Invasion Alters Nitrogen Dynamics in an Arid Grassland. Ecol. Appl. 11, 1301-1310.

Fernandez, C.W., Kennedy, P.G., 2016. Revisiting the "Gadgil effect": Do interguild fungal interactions control carbon cycling in forest soils? New Phytol. 209, 1382-1394. https://doi.org/10.1111/nph.13648

Gadgil, R.L., Gadgil, P.D., 1975. Suppression of litter decomposition by mycorrhizal roots of Pinus radiata. New Zeal. J. For. Sci. 5, 33-41. 
431

432

433

434

435

436

437

438

439

440

441

442

443

444

445

446

447

448

449

450

451

452

453

454

455

456

457

458

459

460

461

462

463

464

465

466

467

468

469

Gadgil, R.L., Gadgil, P.D., 1971. Mycorrhiza and litter decomposition. Nature 233, 133. https://doi.org/10.1038/233133a0

Gardes, M., Bruns, T.D., 1993. ITS primers with enhanced specificity for basidiomycetes application to the identification of mycorrhizae and rusts. Mol. Ecol. 2, 113-118. https://doi.org/10.1111/j.1365-294X.1993.tb00005.x

Hågvar, S., 1998. The relevance of the Rio-Convention on biodiversity to conserving the biodiversity of soils. Appl. Soil Ecol. 9, 1-7. https://doi.org/10.1016/S0929-1393(98)00115-2

Harrell, F., 2021. Hmisc R package.

Hopkins, M.S., Reddell, P., Hewett, R.K., Graham, A.W., 1996. Comparison of root and mycorrhizal characteristics in primary and secondary rainforest on a metamorphic soil in North Queensland, Australia. J. Trop. Ecol. 12, 871-885. https://doi.org/10.1017/S0266467400010130

Hubnerova, Z., Esterby, S., Taylor, S., 2020. Fire-Weather Index and Climate Change, in: Evaluating Climate Change Impacts. Chapman and Hall/CRC, pp. 45-63. https://doi.org/10.1201/9781351190831-3

Keenan, T.F., Williams, C.A., 2018. The Terrestrial Carbon Sink. Annu. Rev. Environ. Resour 43, 219-243. https://doi.org/10.1146/annurev-environ

Kipfer, T., Moser, B., Egli, S., Wohlgemuth, T., Ghazoul, J., 2011. Ectomycorrhiza succession patterns in Pinus sylvestris forests after stand-replacing fire in the Central Alps. Oecologia 167, 219-228. https://doi.org/10.1007/s00442-011-1981-5

Kraisitudomsook, N., Healy, R.A., Mujic, A.B., Pfister, D.H., Nouhra, E.R., Smith, M.E., 2019. Systematic study of truffles in the genus Ruhlandiella, with the description of two new species from Patagonia. Mycologia 111, 477-492.

https://doi.org/10.1080/00275514.2019.1574490

Le Quéré, C., Andrew, R.M., Friedlingstein, P., Sitch, S., Pongratz, J., Manning, A.C., Korsbakken, J.I., Peters, G.P., Canadell, J.G., Jackson, R.B., Boden, T.A., Tans, P.P., Andrews, O.D., Arora, V.K., Bakker, D.C.E., Barbero, L., Becker, M., Betts, R.A., Bopp, L., Chevallier, F., Chini, L.P., Ciais, P., Cosca, C.E., Cross, J., Currie, K., Gasser, T., Harris, I., Hauck, J., Haverd, V., Houghton, R.A., Hunt, C.W., Hurtt, G., Ilyina, T., Jain, A.K., Kato, E., Kautz, M., Keeling, R.F., Klein Goldewijk, K., Körtzinger, A., Landschützer, P., Lefèvre, N., Lenton, A., Lienert, S., Lima, I., Lombardozzi, D., Metzl, N., Millero, F., Monteiro, P.M.S., Munro, D.R., Nabel, J.E.M.S., Nakaoka, S.-I., Nojiri, Y., Padin, X.A., Peregon, A., Pfeil, B., Pierrot, D., Poulter, B., Rehder, G., Reimer, J., Rödenbeck, C., Schwinger, J., Séférian, R., Skjelvan, I., Stocker, B.D., Tian, H., Tilbrook, B., Tubiello, F.N., Van Der Laan-Luijkx, I.T., Van Der Werf, G.R., Van Heuven, S., Viovy, N., Vuichard, N., Walker, A.P., Watson, A.J., Wiltshire, A.J., Zaehle, S., Zhu, D., 2018. Global Carbon Budget 2017. Earth Syst. Sci. Data 10, 405-448. https://doi.org/10.5194/essd-10-405-2018

LeDuc, S.D., Lilleskov, E.A., Horton, T.R., Rothstein, D.E., 2013. Ectomycorrhizal fungal succession coincides with shifts in organic nitrogen availability and canopy closure in post- 

2471-0

472

473

474

475

476

477

478

479

480

481

482

483

484

485

486

487

488

489

490

491

492

493

494

495

496

497

498

499

500

501

502

503

504

505

506

Longo, S., Urcelay, C., Nouhra, E., 2011. Long term effects of fire on ectomycorrhizas and soil properties in Nothofagus pumilio forests in Argentina. For. Ecol. Manage. 262, 348-354. https://doi.org/10.1016/j.foreco.2011.03.041

Lozupone, C., Knight, R., 2005. UniFrac: a new phylogenetic method for comparing microbial communities. Appl. Environ. Microbiol. 71, 8228-35. https://doi.org/10.1128/AEM.71.12.8228-8235.2005

Lunghini, D., Granito, V.M., Di Lonardo, D.P., Maggi, O., Persiani, A.M., 2013. Fungal diversity of saprotrophic litter fungi in a Mediterranean maquis environment. Mycologia 105, 14991515. https://doi.org/10.3852/13-103

McGuire, K.L., Allison, S.D., Fierer, N., Treseder, K.K., 2013. Ectomycorrhizal-Dominated Boreal and Tropical Forests Have Distinct Fungal Communities, but Analogous Spatial Patterns across Soil Horizons. PLoS One 8, 1-9. https://doi.org/10.1371/journal.pone.0068278

McMullan-Fisher, S.J.M., May, T.W., Keane, P.J., 2002. The macrofungal community and fire in a Mountain Ash forest in southern Australia. Fungal Divers. 10, 57-76.

Neldner, V.J., Clarkson, J.R., 1995. Vegetation Survey and Mapping of Cape York Peninsula, Cape York Peninsula Land Use Strategy. Mareeba.

Nguyen, N.H., Song, Z., Bates, S.T., Branco, S., Tedersoo, L., Menke, J., Schilling, J.S., Kennedy, P.G., 2016. FUNGuild: An open annotation tool for parsing fungal community datasets by ecological guild. Fungal Ecol. 20, 241-248. https://doi.org/10.1016/j.funeco.2015.06.006

NSWDPIA, 2020. Net Zero Plan Stage 1: 2020-2030 [WWW Document]. NSW Dep. Planning, Ind. Environ. URL https://www.environment.nsw.gov.au/topics/climate-change/net-zero-plan (accessed 5.12.21).

Oksanen, J., Blanchet, G., Friendly, M., Kindt, R., Legendre, P., McGlinn, D., Minchin, P.R., O’Hara, R.B., Simpson, G.L., Solymos, P., Henry, M., Stevens, H., Szoecs, E., Wagner, H., 2020. vegan: Community Ecology Package [WWW Document]. R Packag. version 2.5-6. URL https://cran.r-project.org/package=vegan

Ondei, S., Prior, L.D., Vigilante, T., Bowman, D.M.J.S., 2016. Post-fire resprouting strategies of rainforest and savanna saplings along the rainforest-savanna boundary in the Australian monsoon tropics. Plant Ecol. 217, 711-724. https://doi.org/10.1007/s11258-015-0531-3

Ondov, B.D., Bergman, N.H., Phillippy, A.M., 2011. Interactive metagenomic visualization in a Web browser. BMC Bioinformatics 385.

Owen, S.M., Patterson, A.M., Gehring, C.A., Sieg, C.H., Baggett, L.S., Fulé, P.Z., 2019. Large, high-severity burn patches limit fungal recovery 13 years after wildfire in a ponderosa pine forest. Soil Biol. Biochem. 139. https://doi.org/10.1016/j.soilbio.2019.107616 
507

508

509

510

511

512

513

514

515

516

517

518

519

520

521

522

523

524

525

526

527

528

529

530

531

532

533

534

535

536

537

538

539

540

541

542

543

544

545

Pellegrini, A.F.A., Hedin, L.O., Stayer, A.C., Govender, N., 2019. Fire alters ecosystem carbon and nutrients but not plant nutrient stoichiometry or composition in tropical savanna Author ( s ): Adam F . A . Pellegrini, Lars O . Hedin, A . Carla Staver and Navashni Govender Published by: Wiley on behalf of the Ecolog 96, 1275-1285.

Rincón, A., Santamaría, B.P., Ocaña, L., Verdú, M., 2014. Structure and phylogenetic diversity of post-fire ectomycorrhizal communities of maritime pine. Mycorrhiza 24, 131-141. https://doi.org/10.1007/s00572-013-0520-0

Salo, K., Domisch, T., Kouki, J., 2019. Forest wildfire and 12 years of post-disturbance succession of saprotrophic macrofungi (Basidiomycota, Ascomycota). For. Ecol. Manage. 451, 117454. https://doi.org/10.1016/j.foreco.2019.117454

Sarmiento, C., Zalamea, P.-C., Dalling, J.W., Davis, A.S., Stump, S.M., U’Ren, J.M., Arnold, A.E., 2017. Soilborne fungi have host affinity and host-specific effects on seed germination and survival in a lowland tropical forest. Proc. Natl. Acad. Sci. 114, 201706324. https://doi.org/10.1073/pnas.1706324114

Shannon, C.E., 1948. A Mathematical Theory of Communication. Bell Syst. Tech. J. 27, 379-423. https://doi.org/10.1002/j.1538-7305.1948.tb01338.x

Silvério, D. V., Brando, P.M., Bustamante, M.M.C., Putz, F.E., Marra, D.M., Levick, S.R., Trumbore, S.E., 2019. Fire, fragmentation, and windstorms: A recipe for tropical forest degradation. J. Ecol. 107, 656-667. https://doi.org/10.1111/1365-2745.13076

Singh, R.S., 1994. Changes in soil nutrients following burning of dry tropical savanna. Int. J. Wildl. Fire 4, 187-194. https://doi.org/10.1071/WF9940187

Team, R.C., 2020. R: A language and environment for statistical computing.

Tecon, R., Or, D., 2017. Biophysical processes supporting the diversity of microbial life in soil. FEMS Microbiol. Rev. 41, 599-623. https://doi.org/10.1093/femsre/fux039

Tedersoo, L., Bahram, M., Põlme, S., Kõljalg, U., Yorou, N., Wijesundera, R., Ruiz, L.V., VascoPalacios, A., Thu, P.Q., Suija, A., Smith, M., Sharp, C., Saluveer, E., Saitta, A., Rosas, M., Riit, T., Ratkowsky, D., Pritsch, K., Põldmaa, K., Piepenbring, M., Phosri, C., Peterson, M., Parts, K., Pärtel, K., Otsing, E., Nouhra, E., Njouonkou, A., Nilsson, R.H., Morgado, L., Mayor, J., May, T., Majuakim, L., Lodge, J., Lee, S.S., Larsson, K.-H., Kohout, P., Hosaka, K., Hiiesalu, I., Henkel, T., Harend, H., Guo, L., Greslebin, A., Grelet, G., Geml, J., Gates, G., Dunstan, W., Dunk, C., Drenkhan, R., Dearnaley, J., Kesel, A. De, Dang, T., Chen, X., Buegger, F., Brearley, F., Bonito, G., Anslan, S., Abell, S., Abarenkov, K., 2014. Disentangling global soil fungal diversity. Science (80-. ). 346, 1052-1053. https://doi.org/10.1126/science.aaa1185

Verma, S., Jayakumar, S., 2018. Effect of recurrent fires on soil nutrient dynamics in a tropical dry deciduous forest of Western Ghats, India. J. Sustain. For. 37, 678-690. https://doi.org/10.1080/10549811.2018.1453842

Verma, S., Jayakumar, S., 2012. Impact of forest fire on physical, chemical and biological properties of soil: A review. Proc. Int. Acad. Ecol. Environ. Sci. 2, 168-176. 
546 Verma, S., Singh, D., Singh, A.K., Jayakumar, S., 2019. Post-fire soil nutrient dynamics in a tropical dry deciduous forest of Western Ghats, India. For. Ecosyst. 6. https://doi.org/10.1186/s40663-019-0168-0

Warcup, J., 1990. Occurrence of ectomycorrhizal and saprophytic discomycetes after a wild fire in a eucalypt forest. Mycol. Res. 94, 1065-1069. https://doi.org/10.1016/S09537562(09)81334-8

Webb, L.J., 1959. A Physiognomic Classification of Australian Rain Forests. J. Ecol. 47, 551. https://doi.org/10.2307/2257290

White, T., Bruns, T., Lee, S., Taylor, J., 1990. Amplification and direct sequencing of fungal ribosomal RNA genes for phylogenetics, PCR protocols: a guide to methods and applications.

Wu, L., Feinstein, L.M., Valverde-Barrantes, O., Kershner, M.W., Leff, L.G., Blackwood, C.B., 2011. Placing the Effects of Leaf Litter Diversity on Saprotrophic Microorganisms in the Context of Leaf Type and Habitat. Microb. Ecol. 61, 399-409. https://doi.org/10.1007/s00248-010-9760-0

561 Zhou, Y., Mushinski, R.M., Hyodo, A., Ben Wu, X., Boutton, T.W., 2018. Vegetation change alters

562 soil profile $\delta 15 \mathrm{~N}$ values at the landscape scale. Soil Biol. Biochem. 119, 110-120.

563 https://doi.org/10.1016/j.soilbio.2018.01.012 